\title{
Marine reserves along the Sinai Peninsula (northern Red Sea)
}

\author{
L. Fishelson \\ Department of Zoology, George S. Wise Faculty of Life Sciences, Tel Aviv University; \\ Tel Aviv, Israel
}

\begin{abstract}
The coral world of the northern Red Sea, situated along the shallow waters of the Sinai Peninsula, has been intensively investigated by Israeli scientists during the last decade. Many aspects of these investigations revealed the presence of unique ecosystems which developed mainly after the last postglacial period less than 10,000 years ago! At this time the cooling of the ambient waters swept out most of the neopleistocenic coral formations, and all the richness and diversity of species observed today evolved after those profound events. At present, typical ecoformations, in which the corals comprise the main part, are found in the northern part of the Gulf of Aqaba, around the southern tip (Tiran Straits) of the Sinai Peninsula, and in the shallow parts of the Gulf of Suez. In 1967 teams of our scientists investigated the marine habitats, and a number of marine parks and sanctuaries, protected by law, have been established. Thus destruction of unique faunal elements is being prevented. Today, with the withdrawal of Israel and the return of Egypt to its territories, such parks should receive much attention and remain protected habitats for the benefit of nature and mankind.
\end{abstract}

\section{INTRODUCTION}

The main purpose of this paper is to present and summarise data about the proposed marine reserves in the Gulf of Eilat (Aqaba) and the Gulf of Suez, but general information about the nature of the northern part of the Red Sea is also included. In addition, I bring together the most important concepts and ideas describing the development of activities of both scientific and political nature associated with the formation of these parks, and describe how numerous scientific works of biologists, ecologists, sociologists and legislators have been incorporated in the concept of reserve establishment. It is also worthwhile mentioning that the Israeli success in promoting marine life protection along the Sinai Peninsula was possible only because the local population and Israeli youth have played a decisive and active role.

\section{ABOUT THE NORTHERN RED SEA}

In its northern part the Red Sea terminates with two finger-like extensions. One, the Gulf of Suez, points toward the north-west and approaches the Mediterranean Sea. The second, the Gulf of Eilat (Aqaba), points toward the north-east and is closed on its northern end by the Arava Desert in Israel and Jordan. Both these Gulfs embrace the uplifted Sinai Peninsula, and although alike in their general structure, they differ in geomorphological and biological qualities. The Gulf of Suez, formed during the early 
Miocene, is a wide but very shallow basin. At its junction with the Red Sea, the Gulf of Suez is about 80-90 $\mathrm{m}$ deep, while in its more northern extent the average depth varies between 20 and $30 \mathrm{~m}$. Along its central trough, that serves for navigation, the depth is much greater. The flat bottom of the Gulf is formed by a some 2000 -m thick layer of mare calcareous sediments and sandstone, as well as by an approximately $3000-\mathrm{m}$ thick layer of evaporites. The shallow waters of this Gulf, as well as the soft sediments of its bottom, are strongly agitated by wave motions causing turbidity and heavy sediment movement. This seems to be the main factor that today moulds the recent coral formations in the Gulf of Suez: Hermatypic reefs in the shape of flat platforms are found only in its southern part, close to the Ras Muhammad and Ras Garra. North of these points some fringing reefs continue until $30^{\circ}$ North, after which only diffuse coral structures are found.

In contrast, the Gulf of Eilat remains a typical segment in the Afro-Syrian Rift System with deep and steep walls. Separated from the Red Sea proper by the straits of Tiran, a narrow passage about $250 \mathrm{~m}$ deep, this Gulf forms a "Mediterranean Sea" characterised by its isolation and water regime, and it differs strikingly from the Red Sea proper. The Gulf of Eilat is $170 \mathrm{~km}$ long, 14 to $26 \mathrm{~km}$ wide and almost $2000 \mathrm{~m}$ deep; it forms a "depthtrap" for sedimentation and silt, whereby sedimented material cannot be re-agitated either by surface or vertical water motions. Because of this, the waters of the Gulf, except in some places near the shores, are exceptionally clear and enable light-transmission and visibility for tens of meters. Except for sporadic landborne influxes of fresh water, occurring in winter along dry stream beds (wadis) there is no supply of fresh water to the Gulf and this factor keeps the planktonic primary production low, adding to the water transparency. Surrounded by high mountains, this "desert sea" has a very high rate of evaporation, producing a salinity between 4.02 to $4.1 \%$, and in shallow sites even higher. The temperature of the water ranges between $21^{\circ} \mathrm{C}$ at the bottom to $26^{\circ}$ at the surface (Klinker et al., 1978), and during the summer increases to $27-29^{\circ}$ in shallow, inshore waters (Fishelson, personal observations). As shown by Klinker et al. (1976) the oxygen content in the water column is 3.8 to $5.8 \mathrm{ml} / 1$ throughout the year. The water masses in the Gulf of Eilat have a characteristic circulation pattern caused by a constant influx of water from the Red Sea proper, as well as by northern winds and coriolis forces (Klinker et al., 1976). These water movements not only shift and replace water masses, but also produce typical near-shore local currents that influence the displacement of sediments, as well as the form of growth of various coral formations (Fishelson, 1971). All these conditions - low silt load, high water temperature and high oxygen content enable a luxurious growth of corals, exceptionally high in their diversity of forms and species, and associated fauna (Por \& Lerner-Segev, 1966; Fishelson, 1970a, 1971, 1973a; Loya \& Slobodkin, 1971; Mergner, 1971; Loya, 1972; Mergner \& Schumacher, 1974; Amoreux et al., 1978). These corals form a fringing belt that in the Gulf of Eilat extends along almost the whole shoreline of the southern part of the Sinai Peninsula, partly interrupted by shallow bays. In such places the winter floods of fresh water enriched with silt, depress the normal development of coral growth. The width and thickness of the near-shore coral belt depend on the steepness of the inorganic slopes on which the corals rest. On most sites of the Gulf this base-line is formed by the descending and submerging magnetic mountains of the uplifted Sinai Peninsula. On several northern sites of the Gulf these rocks descend directly into the sea, while in more southern parts, such as north of Sharem e Sheik, the praecambrium formations retreat revealing late 
pleistocenic uplifts of coral reefs, exposed at various elevations above the recent coastline. As shown by various analyses these exposed coral terraces are between 20,000 and 200,000 years old, while some of the fossil parts found in the northern part of the Gulf of Eilat are only approximately 5000 years old (Friedman, 1965, 1968).

These differences in type of shore, slope graduation, as well as the direction which the shore faces, produce a high variety of intimate coral formations, different in their faunal composition as well as in structure. Recently it was discovered that minor local tectonic fractures, occurring along the Gulf axis and close to the coastline, also contribute to the high heterogeneity of the coral formations observed. (The effect of other factors will be elaborated later.) This heterogeneity of corals has produced a fine grained habitat, in which not only hundreds of corals but also thousands of other invertebrates can be found. Approximately one thousand species of fish feed, reproduce and survive among these corals. This high diversity of animals in comparatively narrow sites leads to special types of interspecific relation among sessile animals (Fishelson, 1964, 1970b, 1973a, 1975; Springer \& Smith-Vaniz, 1972; Popper \& Fishelson, 1973; Slobodkin \& Fishelson, 1974; Benayahu \& Loya, 1977; Spiegel, 1979). As a result, a delicate multichannel network of interdependence is formed in which the welfare of one form is tied to the well being of others. As previously mentioned (Fishelson, 1973a) "sometimes one has the impression that we are exploring an ancient fauna, whose main structures were formed during the Pleistocene, and partly only persist to the present time". It is no exaggeration to say that an intact coral reef in the Gulf of Eilat is a polyaxial symbiotic entity, in which each species contributes a vital part. This is the characteristic difference between the Gulf of Suez and the Gulf of Eilat. If the future planned for the Gulf of Suez is to be centered on industry based on oil and its biproducts, the future of the Gulf of Eilat should be to remain a treasure of nature, protected against any harm and destruction. A well-planned tourist industry can be developed, centered around these coral habitats, and especially around the coral parks, a focal point for millions of visitors from the Mediterranean and Europe, for visitors seeking beauty in nature. The investment in the protection of the marine parks will be more than repaid by such visitors. This concept should be the basic premise for developers. In recent times poorly planned human activities have resulted in an increase in catastrophic events, such as oil spills at the oil terminal and the like, with a consequent decline in the stability of natural ecosystems. Such polluting interventions have introduced detrimental changes in coral reefs, examples of which were detected in investigations performed at Eilat (Loya, 1972, 1975, 1976; Fishelson, 1973b; Rinkevich, 1975; Rinkevich \& Loya, 1977; Loya \& Rinkevich, 1979). The deterioration observed in corals was also observed in other animals utilising the coral environment (Fishelson, 1977a). Thus in establishing marine parks we must realise that factors which are likely to contribute to deterioration in the system may derive from human activity on the coastline or on the land. It appears that unwise planning for the use of the marine shallows presents the greatest potential danger for marine parks, as evident from examples from Hawaii, Jamaica and Eilat.

\section{CORAL REEFS IN THE GULF OF EILAT}

The most prominent characteristic of the coral reefs in this Gulf is the high diversity of corals observed (Loya \& Slobodkin, 1971; Loya, 1972; Fishelson, 1973b; Benayahu \& 
Loya, 1976). It is the only habitat in which along a $10-\mathrm{m}$ long transect 12 to 14 coral species could be counted in shallow waters, and about 30 species in deeper waters. At least in the shallows, it seems that just a few important parameters act to conserve such a diversity, which was also observed in other animals inhabiting this system.

\section{Postglacial cold or mesolitic cooling}

As shown by several investigations (Friedman, personal communication) the limestone fossil coral platforms on which the living coral world is based are 10-12,000 years old. It has been also shown that some massive coral skeletons of non-metamorphic aragonite that were found in these platforms are about 9-10,000 years old. This means that some 12-15 thousand years ago a kill occurred in this region that destroyed the then flourishing huge coral reefs in the surrounding Sinai Peninsula. Two recent findings lend support to this possibility: Israeli botanists and paleogeographers have found artifacts in the Sinai Mountains showing that during the last glacial/postglacial period the climate in this middle-eastern region was much colder than today. According to Reiss et al. (1971), this cooling was accompanied in the eastern Mediterranean by a lowering of the sea level, an event which may have also occurred in the northern Red Sea. Recently, deep cores performed by W.H.O.I. in the Gulf of Eilat revealed forms of Globigerina (Foraminifera) typical today for the colder waters of the Atlantic. Again, the dating of these forms is $12-14,000$ years (Reiss, personal communication). If we assume that this marks a water temperature $5-7^{\circ} \mathrm{C}$ lower than today, this will explain the "sudden" kill of the ancient coral belt. A warming up of this region started after this period, and according to Parker (1958) 7000 years ago the Mediterranean was warmer than today. Thus the corals that we see today, accompanied by many other invertebrates and fish, re-invaded the fossilized limestone tables after the Sinai waters were warmed up again. Such a drastic environmental change can result in an explosive evolution, typical for border regions. This can at least partly explain the high endemism of many animal groups observed in the Red Sea (Klausewitz, 1974, 1978; Por, 1978).

\section{Catastrophic low tides}

The surface current pattern in the Gulf is strongly influenced by wind direction and velocity, especially during the strong monsoon winds. It has been observed (Fishelson, 1973a) that if such north/south winds coincide with the neap tides of the months September/October, then this additional force is capable of moving huge masses of water southwards, thereby causing a temporary catastrophic reduction in the water level. This exposes the entire shallow water coral population, and if it continues for several hours during the hot part of the day a kill of corals occurs (Fishelson, 1973a). As the situation changes and the denuded corals submerge, the exposed limestone of their skeletons provides sites for re-settlement for corals (Loya $a_{r} 1976$ ). Such kills seem to occur in the northern part of the Gulf of Eilat every 20-40 years, preventing the development of a climax-situation, and re-establishing successive stages of development. Since shallow water corals produce propagules which can also grow in deeper waters, it seems that the deeper coral populations are also influenced by these unpredicted events. 


\section{Slope-angle and direction of the base-rock}

The angle of the descending slopes of the praecambrium magmatic or sedimentary rocks, which form the base for the coral limestone, is highly variable at various sites along the coast line, ranging between 5 to $14^{\circ}$. This results in very important differences in the amount of support provided to corals within the vital zone of their recruitment and growth. Furthermore, the direction these slopes face may be either leeward or windward at different sites. These characteristics of the base strongly influence the width, density and faunal composition of the coral growths. In general it can be stated that the more gentle the slope the greater will be the possibility for coral settlement and development, and the wider will be the coral table.

\section{Fresh water drainage}

The water-shed of the southern Sinai mountains runs parallel to the Gulf of Eilat, closer to this Gulf than to the Gulf of Suez. From these mountains dry-bed drainages (wadis) open to both Gulfs. Those that empty into the Gulf of Eilat are short and strong while those opening into the Gulf of Suez are longer and more gently inclined. In winter these wadis sporadically flow with huge amounts of rainfall together with silt and rocks. When alluvial sediments settle in the shallow-subtidal they produce fans that cover and kill most of the benthic life found here and so prevent the development of a closed reef along the various larger or smaller bays, including Nweibe and Dahab. These alluvial fans produce special types of lagunar development, with characteristic coral communities on the seaward facing shoulders of the bays.

\section{CORAL ECOTYPES ON THE REEFS OF THE GULF OF EILAT}

About 110 species of hermatypic corals and almost 120 species of soft corals comprise the bulk of the coral reefs in the Gulf of Eilat. An important role in these reefs is also played by two hydrocoralian species, Millepora dichotoma and M. platyphyla, that form dense belts along many coral platforms. Loya (1976) showed that some of these corals, such as Stylophora pistillata are typical $r$-strategists characterised by very high reproductive rate, high growth rates and short life span. Among the branching forms of corals, prolonged observations support the assumption that many belong to this category of expanding species that are rapid invaders with a short life span. As mentioned by Fishelson (1971) some of them are even able to grow on aerial roots of mangroves. These ecotypes numerically dominate many sites in the shallow water reefs, react sharply to deterioration (Fishelson, 1973a) but are able to invade again if the conditions improve. These corals are the most important symbiotic forms, providing homes for very many fish (Fishelson, 1964, 1977b; Fishelson et al., 1974) and various invertebrates (Wolodarsky, 1979).

The globular, brain-shaped corals form a totally different ecotype. The most common are Platygyra lamellina, Favia favus, F. stelligera, F. dereyensis, Favites virens, F. halicora, $F$. abdita; they are characterized by very low propagule-production, a very low growth rate and a great longevity and rapid regeneration rate (Fishelson, 1973a). Small 
colonies of these species, with a diameter of $60-70 \mathrm{~mm}$, add $2-3 \%$ to their initial dimensions each year and colonies of Platygyra lamellina of 40-50 cm diameter grow less than $1 \%$ per year (Fishelson, in preparation). The growth of larger colonies can be detected only after 2-3 years of measurement. On the basis of these observations calculations showed that colonies of these species that are 2-3 $\mathrm{m}$ in diameter are several hundred years old, and larger colonies possibly "remember Moses." It seems that such immortal forms are the moulding components of the reef, providing its stability, while the short-living forms fill up all the space available. The dominance of such ephemeral forms on the reef only exposes its temporal and changing character.

Only by measuring the age-structure (dimension) of massive corals found on various places of the reef are we able to detect long-term changes in the environment, as for example those caused by industrial input (Fishelson, 1977a). On the basis of such data we are also able to predict the long-term outcome of such technological inputs on coral reef stability.

\section{FIRST MARINE PARK IN THE RED SEA}

Prior to 1967, the Israeli shoreline covered by reefs in the Gulf of Eilat was only several $\mathrm{km}$ long. From this a coral reserve was laid out and established in 1960 . To implement the reserve required legislation and special wardens were posted on this 700 $\mathrm{m}$ long strip of shoreline. Most important was the total prohibition of collecting or damaging corals. Unfortunately this Israeli coral reserve is only $1 \mathrm{~km}$ from the harbour, which includes a phosphate loading station and oil terminal. As a result of activity in the harbour a marked decrease in the living coral cover was soon observed (Fishelson, 1973b). During all these years, the rich coral formations of the Gulf of Eilat as well as the entire Sinai Peninsula bordering the Gulf were threatened by the explosive technological development and tourism, so typical of the contemporary Middle East. After the sixday war of 1967, as the Israeli defence forces occupied the Sinai Peninsula, the corals were exposed to an immediate and real danger of destruction by herds of souvenir collectors and animal hunters. This potential for disaster activated the main bodies involved in nature protection: the Association for the Protection of Nature, the Nature Reserve Authority (governmental) and Israeli scientists working on the ecology of the marine ecosystems and involved in policies of conservation. All these united to engage in a wide range of activities, aimed toward the immediate establishment of marine parks along the Gulf of Eilat as well as sections of the Gulf of Suez. Simultaneously with such political activities, all the reefs along Sinai were studied in detail. Similarly the habits of local Bedouin populations especially concerning their fishing activities and seafood collecting were studied. The existing conservation legislature of Israel, as well as the Martial Laws of the Israeli Command in Sinai, made it possible to prepare the necessary legal framework for the establishment of protected areas within a very short time. During this the executive bodies were taught by marine ecologists that: (1) Preserving natural landscapes and resources is a basic need of stable human populations. (2) The coral reefs of the northern Red Sea are a unique natural treasure not found in other parts of the world. (3) Coral reefs are sources of income because they attract tourism and as such provide livelihoods with little capital investment. (4) Well-planned land development can occur without destruction of shallow water habitats. 
Parallel to this the local Bedouins of Sinai, as well as the new Israeli settlers of the Sinai, were taught that: (1) By protecting corals we are preserving focal points for income. (2) Coral reefs are hatcheries and breeding grounds for many fish and other species that serve as food for humans.

The first victory in the battle for corals was the planning of the route for the new road connecting Eilat with Sharem e Sheik on the southern end of the Sinai Peninsula. This road was planned by an interdisciplinary team and goes in part along the sea, but for a long stretch of about $100 \mathrm{~km}$ penetrates inland between the mountains, leaving a large portion of the coral coast almost unapproachable to most visitors (Fig. 1). This was a costly road, but today it is known as one of the most beautiful routes in this part of the world. At the same time several research expeditions along the littoral zone were generously sponsored by the government and military, using landing craft, small boats, military carriers and aeroplanes. Soon enough material was on hand to draw up a plan which laid out both marine reserves and between them officially open fishing grounds. All this was then published on a special chart distributed by the Reserve Authority. By using newspapers, broadcasting and other media, the basic code of marine reserve protection laws was also widely published. The most important among the laws were: (1) All corals and many "non-edible" fish and invertebrates are totally protected and any damage or collection of them not authorised by the authorities will be punished. (2) Waste disposal of any kind in the reef region is forbidden and punishable. (3) Fishing

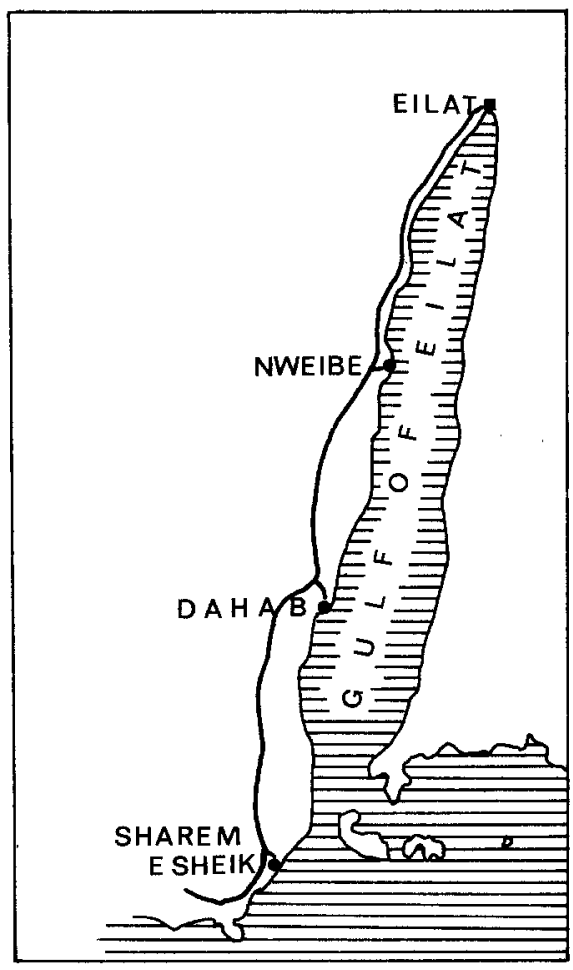

Fig. 1. The road from Eilat to Sharem e Sheik (black line) 
activities in the marine reserves are forbidden. Fishing by special permission is possible in special areas designed for this. Recently a martial court of law totally banned spear fishing along the Sinai Peninsula.

The following concepts were the guidelines for selection of sites along the coral reefs for marine reserves: (1) They should preserve the variety of the coral habitats. (2) The boundaries must be well defined and easy to mark. (3) If possible, areas around these spaces should be preserved for the establishment of visitor services.

As a result several different types of coral habitats, very special in their composition and structure, were chosen and marked as marine reserves, and their borders were well marked with signs. Bedouin and Israeli wardens employed by the Nature Reserve Authority were stationed on these reserves. Today the coral reef reserves include: the lagoonar reefs, platform reefs, contour reefs, sharem reefs, mangrove reserve and coral islets. In some places, such as Ras Muhammad where several of these unique reefs occur close together, the total area has been proclaimed as a marine reserve.

\section{MARINE RESERVES IN THE GULF OF ELLAT}

\section{Lagoonar reef reserves}

This type of reef (Fig. 2) is characterised by a back reef channel (lagoon) that separates the recent reef structure from the beach rock structures on the shoreline (Fishelson, 1971; Fishelson et al., 1974). The bottom in these channels is calcareous, formed mostly from coral debris produced by animals feeding on corals, such as fish (Scaridae, Labridae, Serranider) and various invertebrates. It seems that such channels are formed by the growth destruction differences in the part of the coral situated behind the fore reef parts of the structure. Measurements show that during low tides the summer temperatures in the shallow water reach $29-30^{\circ} \mathrm{C}$ and oxygen depletion occurs in these channels, with oxygen concentration sometimes falling to 3-4 mg/l/ $0_{2}$ as compared with $8-8.5 \mathrm{mg} / \mathrm{l} / \mathrm{O}_{2}$ in the fore reef. The depletion of oxygen must be even more pronounced in the coral crevices and caves and may cause intensive degeneration and prevent growth and regeneration. If these processes occur over longer periods, they, as well as other

LAGOONAR REEF

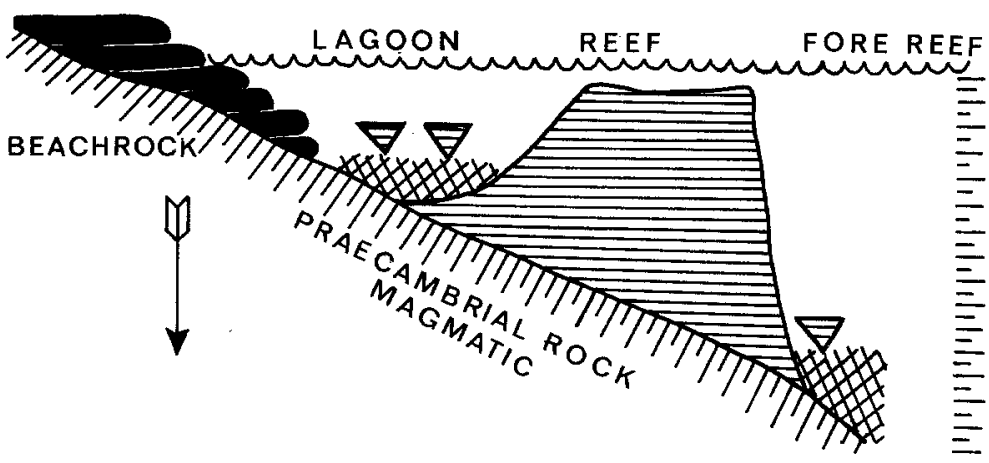

Fig. 2. Cross-section of a lagoonar reef 
factors (e.g. tectonic), will lead toward the destruction of corals and channel formation. A unique fauna develops in this channel which uses the soft bottom as a refuge. It includes saurid fish, gobies and their alpheid symbionts, as well as several species of grounddwelling sea-anemones of the genera Radianthus and Cerianthus. The opportunistic coral Stylophora pistillata as well as colonies of Seriatopora caliendrum and Acropora variabilis are found here, usually populated by highly interesting harems of fish, of various species of Dascyllus spp. (Pomacentridae) and species of Gobiodon and Paragobiodon, special gobies adapted to live between coral branches. During high waters these channels serve as nursing grounds for schools of many commercially important fish, such as goat fish, rabbit fish and porgies. The reef fringing this channel is normally flat, several tens of meters wide, situated $25-35 \mathrm{~cm}$ below the normal low water mark and covered by many species of hermatypic corals and extensive growths of various alcyonarians. Due to very strong growth along the uppermost fringe of this reef, the seaward facing line is slightly elevated compared with other parts of the lagoonar reef. Caves in this structure serve as refuges for nocturnally active fish, such as Pompheridae, Halocentridae, Apogonidae and others. On the seaward side, the upper fore reef is occupied by large colonies of Millepora dichotoma, several species of Acropora (variabilis, humilis), Pocillopora danae and large corals. Most of the typical reef fish live along the fore reef, each of them using it in a different way. The most typical fishes of this fringe are Acanthurus sohal, a crevice dweller feeding on algae, and the butterfly fish Chaetodon strigosus, living over Acropora hyazinthus colonies and feeding on their polyps. During night-time, however, numerous cardinal fish and their main predators, the lion fish are active. Although lagoonar reefs are found at several places along the Gulf of Eilat, the marine reserves are those of the coral reserve in Eilat, and the beautiful reserve on Ras Burkha (29 $\left.13^{\prime} \mathrm{N}\right)$.

\section{Platform reef}

This type of coral formation (Fig. 3) is found chiefly in the southern part of the Gulf of Eilat, although small sites in the north are of the same morphology. Typically, these reefs form a continuous platform from the beach-rock of the shoreline to the fore reef portion

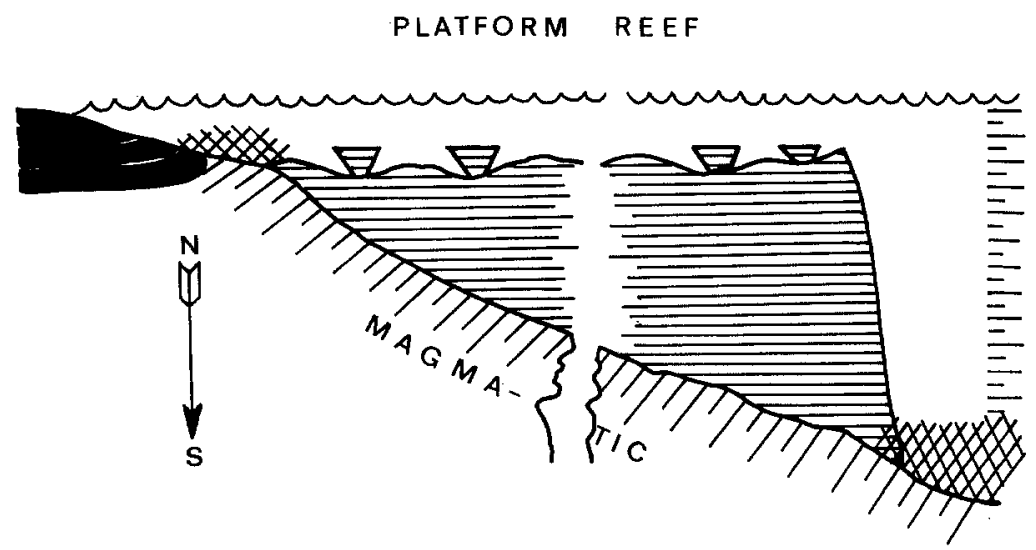

Fig. 3. Cross-section of a platform reef (see also Fig. 2) 
(Safriel \& Lipkin, 1964). Usually the seaward wall of the reef has a stepped or gentle slope, and descends to great depth, sometimes to $100-150 \mathrm{~m}$ as in reefs close to the straits of Tiran. The width of the platform reefs is usually $30-40 \mathrm{~m}$, but in some sites extends over $150 \mathrm{~m}$. The upper surface of the platform is strongly eroded and perforated by caves and passages and its greater part has oval or prolonged intertwining shallow ponds, the result of dissolving metagenesis of the reef structure. Close to the shoreline this surface is dominated by many groups of invertebrates, of which the most dominant are serpent stars of the genus Ophiocoma spp. and the sea-urchin Echinometra mathae (Fishelson, 1971). Only further out from the shore coral colonies start to appear, together with giant shell (Tridacna), conches (Strombus tricornis) and many other species. The crevices of the platform serve as nurseries for many juvenile fish, especially from among the pomacentrid and chaetodontid fish families. Within the crevices conger fish, myrichtyid and muraenichthyid eel-fish find their refuge. Further seaward the platform gradually becomes covered by larger and denser coral growths, especially of Acropora scandens, A. humilis and A. variabilis, Pocillopora danae, smaller heads of Platygyra lamiellina, Favites abdita, Favia favus and Cyphastrea microphtalma. Approximately $10-22 \mathrm{~m}$ before the fore reef fringe the platform becomes deeply eroded with large undercuts, spear growths and disconnected pinnacles and larger coral colonies. Here the largest growths of corals are observed - Acropora scandens and A. hyazinthus of 3-4 m diameter. Favia doreyensis and Goniopora savignyi intermingled with giant Porites lutea, Platygyra lamellina, as well as large growths of the alcyonaria: Labophytum pauciflorum, Sinularia spp. Cladiella spp. and Sarcophytum spp. (Fishelson, 1970a; Benayahu, 1976). Dispersed among them are large colonies of Millepera dichotoma and $M$. platyphyla. All this front of the platform reef is biogenic, like a dense coral garden. As the forewall descends $15-20 \mathrm{~m}$ gorgonarian corals begin to appear forming large growths of various colours, bush-like or fanlike as the giant Suberogorgia. All these subsites of the platform swarm with thousands of fish, many of them stationary, forming typical fish species associations around knolls and pinnacles and along the wall. Other fish species move along in groups or singly seeking food and refuge (Fishelson, 1977b). During night-time thousands of lantern fish (Photoblepharon) are found along these walls and on them many featherstars and gorgonian heads (Astroboa nuda) may be seen (Fishelson, 1974).

The most well preserved platform reefs are found at Ras Atantur $\left(28^{\circ} 14^{\prime} \mathrm{N}\right)$, south of Nabeq, and from Ras Nazrani to Ras Muhammad.

\section{Contour reef}

This type of reef is like a platform reef in general structure, but differs from it in the dimension and mass of limestone on which it rests. Contour reefs develop on sites where the magmatic mountains submerge into the sea and continue to descend almost along a straight line. Such a structure does not provide sufficient support for colonisation and development of large biogenic communities (Fig. 4). Because of this, only a very narrow band of corals develop forming a narrow frame attached to the supporting inorganic slope. Such contour reefs are sometimes only 3-4 m wide and seawards of them the plunge to the depths begins. Compared with other reefs, the contour reefs are poorer in diversity, but the sharp contrast between the narrow shallow coral belt and the deep blue 


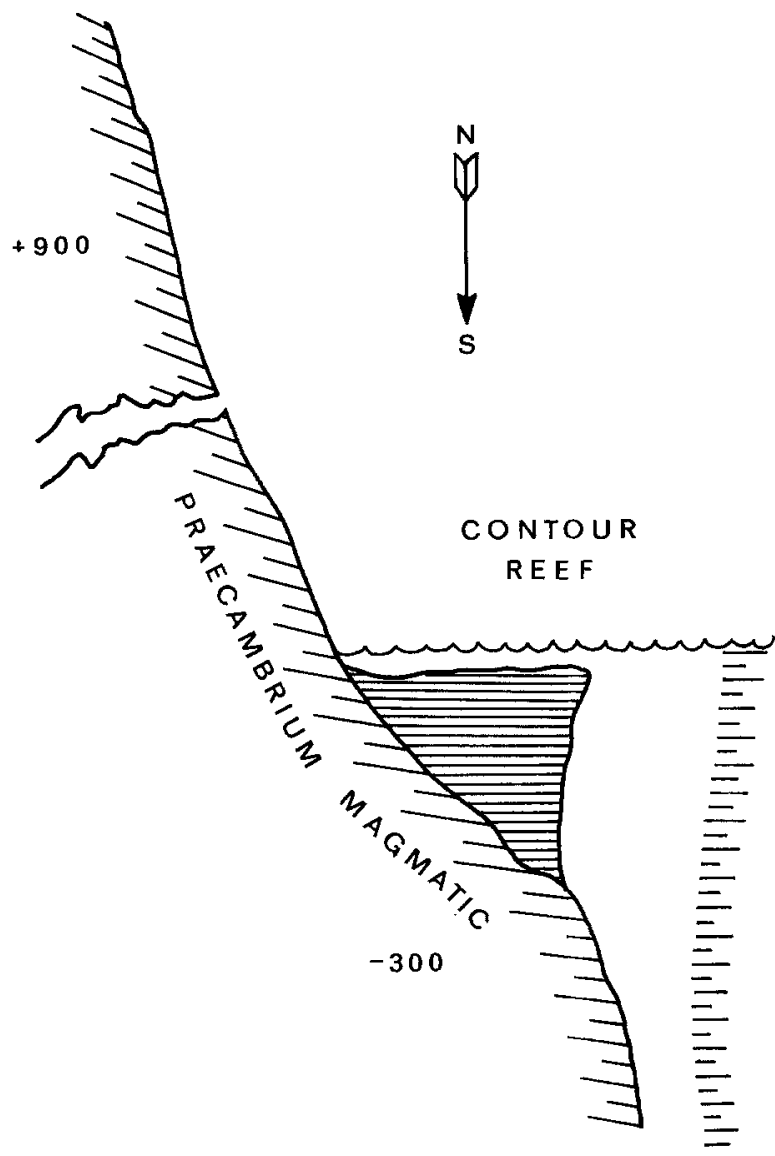

Fig. 4. Cross-section of a contour reef

sea is very impressive visually. On the rocky seaward slope, below the narrow coral belt, growths of gorgonaria and alcyonaria develop, as well as sponges of various forms and colours. The most developed contour reefs are found south of Dahab.

\section{Sharem reefs}

This type of reef (Fig. 5) frequently includes elements of the various reef types described above, and develops around and within bays, which are numerous around the Sinai Peninsula. As mentioned previously, several larger or smaller wadis terminate today or once terminated along the shores of the Gulf of Eilat. In such surroundings bays are formed, frequently used by the local population as anchorages for their small seagoing vessels. Along such sites there are small villages occupied by Bedouins, who spend at least part of the year fishing. The central axis of such a sharem has a soft bottom covered by a mixture of silt and calcareous sand, usually with growths of Halophila stipulacea or other sea grasses. The dominating organism in these bottoms is Lovenia 


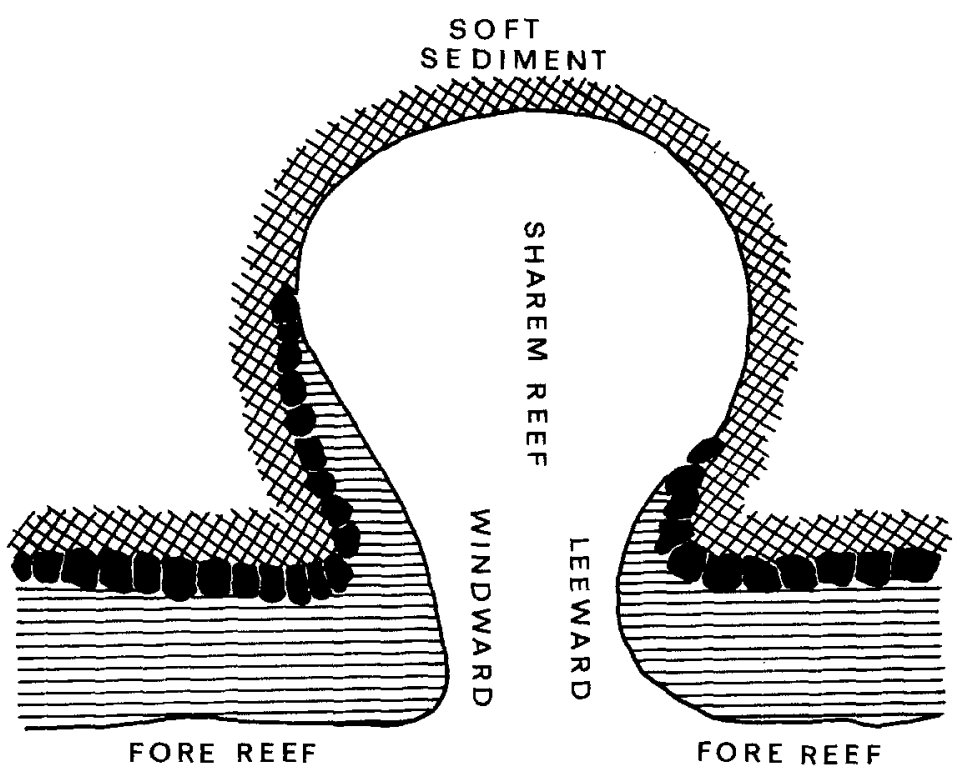

Fig. 5. Aerial view of a sharem reef (see also Fig. 2)

elongata (Farber \& Lawrence, 1976). Approaching the shore, the bottom becomes more heavily covered by gravel and stones, brought down by strong floods in the wadis. These shifting alluvial deposits prevent coral development along the internal part of the sharem, and only small, one-to-two-year old colonies of Stylophora pistillata, Pocillopora danae and various faviids are found attached to these stones. The coral reefs develop along the sides of the embayment, usually starting as narrow and eroded coralogenous rocks at half the depth of the bays. Toward the bay opening the coral habitats gradually widen and living coral cover becomes more pronounced. In such places $20-30 \%$ of the coral flats is covered by living colonies, and toward the bay entrance the cover becomes larger and denser. Here also the diversity of species of corals on the leaward and windward sides of the embayments becomes more pronounced. As an example we may take the Maagana Sharem $\left(20^{\circ} 07^{\prime} \mathrm{N}\right)$, one of the beautiful sharem reefs in the northern part of the Gulf of Eilat. On the northern, leeward coral shoulder of this sharem the plate of corals is highly eroded and covered by small colonies of Acropora spp., Stylophora pistillata, Pavona decussata, Cyphastrea microphthalma, and a few small faviids. Toward the fringe, larger colonies of Millepora dichotoma form the frame of the reef. At the bay entrance larger colonies of corals develop, especially globular forms and Millepora platyphyla. The fore reef wall of this part of reef is in many parts covered by growths of Lobophytum pauciflorum and Sarcophytum glaucum (Alcyonaria). Gradually large colonies of Acropora hyazinthus take over toward the open sea. The windward side of the Maagana sharem, is totally different. Here is the domain of heavy, massive corals, among which also branching forms are frequently found. Deeper in the bay, the colonies are smaller, but toward the opening, huge colonies of Millepora dichotoma and $M$. platyphyla (Hydrocoralina) form very strong outgrowths, sometimes forming separated 
pinnacles. The bay-facing wall of the coral platform is covered by large colonies of Favia specioza and Porites lutea, sometimes globular or columnar, of several meters dimension. Among them are also globular larger colonies of Platygyra lamellina, various species of Favites, Cyphastrea and Hydnopora. This entire sea-facing wall, which is exposed to the heaviest breakers, is protected by such massive forms. Branching corals or soft forms of alcyonaria are of major importance on this site as compared with the leeward side of the sharem. Sharem reefs are very rich in coral fish of various families, and especially important here are the breeding groups of Abudefduf sordidus, very rare on other sites of the Gulf. Many juveniles of coral fish find their protection from predators in crevices of these reefs. The holes in the fore part serve as hiding places for spiny lobsters Panulirus penicilliatus.

\section{Coral islets}

Few coral islets are found in the northern Red Sea, as compared with the southern, where the Dahlak Archipelago contains the largest aggregation of them (Lewinsohn \& Fishelson, 1967). We define an island as biogenic parts of land separated from the mainland by deeper sea. Such groups of islets are situated north to Nweibe, not far from the shoreline. During high tide these coral islets are submerged, and only breakers indicate their position. During low tides, their upper parts are exposed and they can be seen from the shore. Such coral outcrops are gardens of corals, inhabited by myriads of fish. The water around them is always clear and deep blue. The northern side is usually more exposed to water agitation than the southern, and because of this the globular or heavy masses of corals are more pronounced here.

A special island, called Coral Island (or in Arabic Jezirat Farun) is found in the northern part of the Gulf of Eilat $\left(29^{\circ} 27^{\prime} \mathrm{N}\right)$. This island is a metamorphic, magmatic rocky fragment separated from the land by a narrow deep channel. The island has steep slopes, plunging into the deep sea, especially on its eastern and northern side. The southern side is flatter, and here a coral patch reef is formed. On this island well preserved archaeological remains are found of strongholds from the Byzantine and early Arabian times. All this together makes the Coral Island a worthy reserve. At a site on the opposite shore, facilities are provided for tourists.

\section{Mangrove reef}

Mangrove forests are the trade-mark of shallow water marine and brackish estuaries of the tropical and subtropical regions, where they form extensive habitats (Fig. 6), composed of trees from several families, all of them adapted to high salinity and evaporation (Leshem \& Levison, 1977). In the southern Red Sea, several mangrove species form extensive habitats, while only one, Avicennia marina, advances toward the most northern limits of mangrove distribution, forming two groves on the Sinai Peninsula. One of these is situated in the Gulf of Eilat, between Shurat el Manqata $\left(28^{\circ} 13^{\prime} N\right)$ and El-shira el Ghargana $\left(28^{\circ} 04^{\prime} \mathrm{N}\right)$ forming several subdivided groupings. Rising above the sea level between the flat and desolate desert from the east, and between the coral reef and blue sea in the west, this mangrove oasis is exceptionally beautiful. Birds breed in the tree tops, and crabs, molluscs and corals hang on the trees'submerged parts. The 


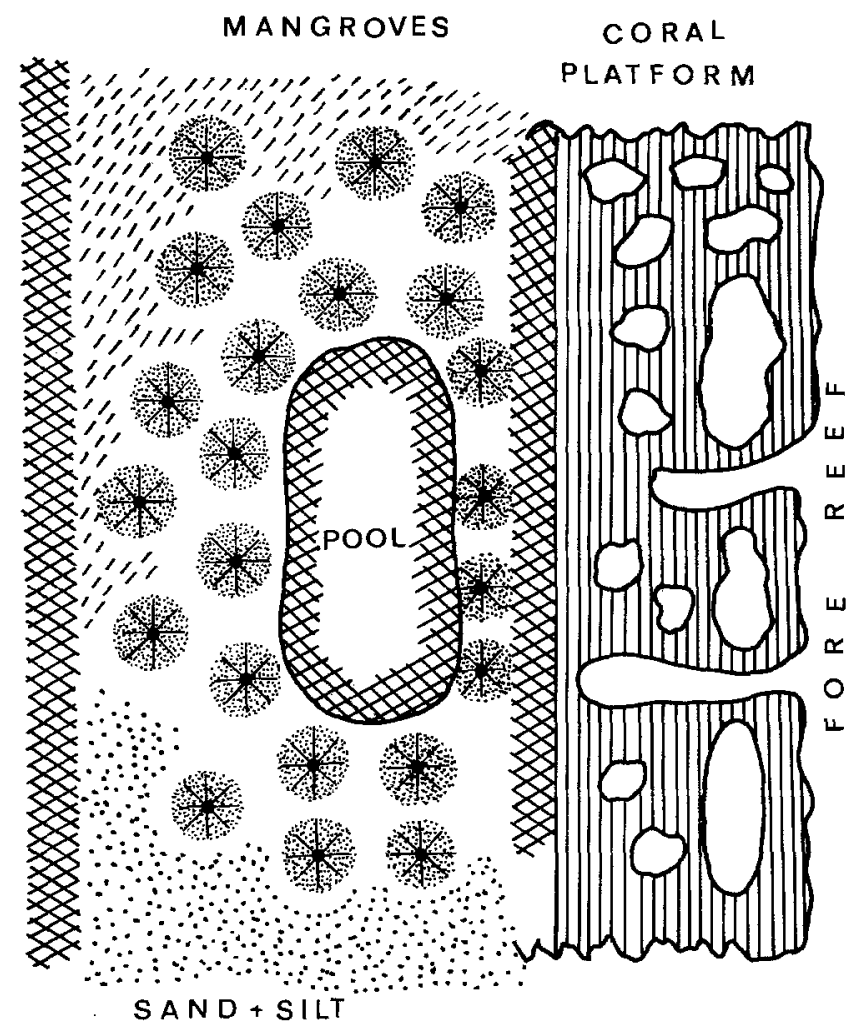

Fig. 6. Aerial view of a mangrove reef

shoreline, formed mostly by alluvial salty silt and juvenile conglomerates, meets a large, silty sand flat, that partly covers the subfossil, dead limestone of corals. This flat is the habitat of a dense population of various ghost crabs (Ocypoda sarratan, Dotilla sulcata) and three species of the fiddler crabs (Uca spp.). During low tides these flats swarm with crabs, which feed, dig or dísplay for mates. In the middle of the flats the aerial roots of Avicenia marina begin to appear and, approaching the subtidal zone, the trees become denser and taller. As reported by several authors (Fishelson, 1971; Por et al., 1977) these trees form a unique habitat, populated by many invertebrate species and several species of fish. Seawards large dissolution pools are formed, passages within the coral reef tissue along which the warmed up, oxygen-poor ebb wter leaves the littoral and cooler oxygenenriched open-sea water enters the mangrove region. The stability of the internal part of this unique marine reserve depends totally on the regular interchange of waters. Toward the sea, a large coral platform frames the mangroves. This platform is eroded on its upper surface and rich in corals and fish on its fore part, which plunges into the depth of the Gulf.

An additional grove of Avicenia marina is situated in a shallow channel that separates a Pleistocene reef platform on Ras Muhammad from the mainland platform. Here the trees form an alley along the channel, rich in animals typical for such habitats. It seems that in both sites, the mangroves of Sinai are situated on brackish water that 
seeps underground and flows into the sea. Such brackish waters have also been found in deep cracks formed on Ras Muhammad during very recent tectonic movements.

\section{MARINE RESERVES IN THE GULF OF SUEZ}

The Gulf of Suez will play a very important role in the development of oil technology in Egypt, and so major hopes for larger reserves and protected areas are unrealistic. Nevertheless, there are several reef sites along the Sinai coast that are worthy of protection. These include coral reefs south of Et-Tour, at Sheikh Raikh, the outer reefs of Ras Garra and some reefs in the Strait of Gubal. Some shallow sand bays along the Gulf should be given special status since they are important nesting grounds for the seaturtles, Dermochelys coriacea and Chelonia mydas. It seems to me that if more research were to be put into this Gulf, a modus vivendi could be found to permit planned technological development as well as marine life preservation.

\section{MANAGEMENT OF THE MARINE RESERVES}

Following the final decision on where the reserves will be situated, a chart was prepared and this was adopted by the Legislature of Israel. The Nature Reserves Authority provided special funds for marking borders of the reserves and putting up signs in Hebrew, English, French and Arabic, concerning regulations on human activities within the reserves. Along the coastline wardens have been organised and equipped with vehicles. These wardens were responsible for controlling the area within their jurisdiction, from Eilat to Ras Muhammad, and from there along the Gulf of Suez. Within the marine reserves, local watchers were hired from among the Bedouin, and those living on the spot were able to keep an eye on the reserve. For these people a simple set of regulations was provided: (1) No entry into the marine reserve water with any kind of collecting instruments is allowed (except scientists with special permission). (2) No collecting on the shore is allowed. (3) Any damage within the coral region is punishable.

To strengthen the authority of these Reserve Guards, they receive special documents similar to those used by police officers. Furthermore, courses for the marine reserve wardens were organised to teach them about the ecology and biology of coral reefs, fish biology and problems of pollution. Colourful leaflets were distributed for the general public and numerous talks and articles were broadcast and printed in newspapers. Parallel activities were carried out by members of the Association for the Protection of Nature and by university people concerned with conservation and protection. All these activities were possible thanks to the warm approval and helpfulness of the military command in Sinai. Along the shore, between the marine reserves, fishing grounds were open on a part of which only the local Bedouin population was allowed to fish, using the ancient, non-destructive fishing methods.

All these measures, accompanied by enforcement and punishment enable us to establish a firm protection of these beautiful and unique species-rich habitats. Now, with the coming of peace these territories are being returned to Egypt and we hope that the protection of these marine reserves will continue: 


\author{
For the beauty of nature \\ For the common human heritage \\ For the benefits of our region \\ For future scientific cooperation
}

Acknowledgements. I would like to thank Ms. S. Shaffer, Mr. M. A. Shuv and Y. Galil for help with the figures. Special thanks are due to Dr. Amelia Terkel for critical remarks on the English text.

\title{
LITERATURE CITED
}

Amoureux, L., Rullier, F. \& Fishelson, L., 1978. Systématique et écologie d'Annelides Polychètes de la presquil du Sinai. - Israel J. Zool. 27, 57-163.

Benayahu, Y., 1976. Quantitative characteristics of community structure of stony corals, soft corals and algae in the northern Gulf of Eilat (Red Sea). M. Sc. thesis, Tel Aviv University, $132 \mathrm{pp}$.

Benayahu, Y. \& Loya, Y., 1977. Space partitioning by stony corals, soft corals and benthic algae on the coral reefs of the northern Gulf of Eilat (Red Sea). - Helgoländer wiss. Meeresunters. 30, $362-382$.

Farber, I. \& Lawrence, Y. M., 1976. Distribution, substratum preference and burrowing behaviour of Lovenia elongata (Gray). (Echinoidea; Spatangoida) in the Gulf of Eilat (Aqaba), Red Sea. - J. exp. mar. Biol. Ecol. 22, 207-225.

Fishelson, L., 1964. Observations on the biology and behaviour of Red Sea coral Fishes. - Bull. Sea Fish. Res. Stn Israel 37, 11-26.

Fishelson, L., 1970a. Littoral fauna of the Red Sea: The population of non-scleractinian anthozoans of shallow waters of the Red Sea (Eilat). - Mar. Biol. 6, 106-116.

Fishelson, L., $1970 \mathrm{~b}$. Behaviour and ecology of a population of Abudefduf saxatilis (Pomacentridae, Teleostei) at Eilat (Red Sea). - Anim. Behav. 18, 225-237.

Fishelson, L., 1971. Ecology and distribution of the benthic fauna in the shallow waters of the Red Sea. - Mar. Biol. 10, 113-133.

Fishelson, L., 1973a. Ecological and biological phenomena influencing coral-species composition on the reef tables at Eilat. - Mar. Biol. 19, 183-196.

Fishelson, L., 1973b. Ecology of coral reefs in the Gulf of Aqaba (Red Sea) influenced by pollution. Oecologia 12, 55-67.

Fishelson, L., 1974. Ecology of northern Red Sea crinoids and their epi- and endozoid fauna. - Mar. Biol. 26, 183-192.

Fishelson, L., 1975. Sex-reversion in Anthias squamipinnis (Athiidae, Teleostei) in the Gulf of Aqaba (Red Sea). In: Intersexuality in animal kingdom. Ed. by R. Reinboth. Springer, Berlin, 284-294.

Fishelson, L., 1977a. Stability and instability of marine ecosystems, illustrated by examples from the Red Sea. - Helgoländer wiss. Meeresunters. 30, 18-29.

Fishelson, L., 1977b. Sociobiology of feeding behaviour of coral-reef fish along the coral-reef of the Gulf of Eilat, Red Sea. - Israel J. Zool. 26, 114-134.

Fishelson, L., Popper, D. \& Avidor, A., 1974. Biosociology and ecology of Pomacentrid fishes around the Sinai Peninsula (northern Red Sea). - J. Fish Biol. 6, 110-133.

Friedman, G. M., 1965. A fossil shoreline reef in the Gulf of Eilat (Aqaba). - Israel J. Earth-Sci. 14, $86-90$.

Friedman, G. M., 1968. Geology and geochemistry of reefs, carbonate sediments and matters, Gulf of Eilat (Aqaba) Red Sea. - J. sedim. Petrol. 38, 895-919.

Klausewitz, W., 1974. The zoogeographical and paleographical problem of the Indian Ocean and the Red Sea according to the ichthyofauna of the littoral. - J. mar. biol. Ass. India 14, 697-706.

Klausewitz, W., 1978. Zoogeography of the littoral fishes of the Indian Ocean, based on the distribution of the Chaetodontidae and Pomacanthidae. - Senckenberg. biol. 59, 25-39.

Klinker, J., Reiss, Z., Kropach, C., Levanon, I., Harpaz, H., Halich, E. \& Assaf, G., 1976. Observations of the circulation pattern in the Gulf of Eilat (Aqaba), Red Sea. - Israel J. Earth-Sci. 25, 85-103. 
Klinker, J., Reiss, Z., Kropach, C., Levanon, I., Harpaz, H. \& Shapiro, Y., 1978. Nutrients and biomass distribution in the Gulf of Aqaba (Eilat). - Mar. Biol. 45, 53-64.

Leshem, Y. \& Levison, E., 1977. Regulation mechanisms in the salt mangrove Avicenia marina, growing on the Sinai littoral. - Oecol. Plant. 7, 167-176.

Lewinsohn, Ch. \& Fishelson, L., 1967. The second Israel South Red Sea expedition 1965. - Israel J. Zool. 16, 59-68.

Loya, Y., 1972. Community structure and species diversity of hermatypic corals at Eilat, Red Sea. Mar. Biol. 13, 100-123.

Loya, Y., 1975. Possible effect of water pollution on the community structure of Red Sea corals. Mar. Biol. 29, 177-185.

Loya, Y., 1976a. Recolonisation of Red Sea corals as affected by natural catastrophies and manmade perturbations. - Ecology 57, 278-289.

Loya, Y., 1976b. The Red Sea coral Stylophora pistillata is an r strategist. - Nature, Lond. 259, $478-480$.

Loya, Y. \& Rinkevich, B., 1979. Abortion effect in corals induced by oil pollution. - Mar. Ecol. Prog. Ser. 1, 77-80.

Loya, Y. \& Slobodkin, L. B., 1971. The coral reefs of Eilat (Gulf of Eilat, Red Sea). - Symp. Zool. Soc. Lond. 28, 117-139.

Mergner, H., 1971. Structure, ecology and zonation of Red Sea reefs (in comparison with south Indian and Jamaican reefs). - Symp. zool. Soc. Lond. 28, 141-161.

Mergner, H. \& Schuhmacher, H., 1974. Morphologie, Ökologie und Zonierung von Korallenriffen bei Aqaba (Golf von Aqaba, Rotes Meer). - Helgoländer wiss. Meeresunters. 26, 238-358.

Parker, F. L., 1958, Eastern Mediterranean Foraminifera. - Rep. Swed. deep Sea Exped. 8, $219-283$.

Popper, D. \& Fishelson, L., 1973. Ecology and behaviour of Anthias squamipinnis (Peters, 1855) (Anthiidae, Teleostei) in the coral habitat of Eilat (Red Sea). - J. exp. Zool. 184, 409-424.

Por, F. D., 1978. Lessepsian migration. Springer, Berlin, 228 pp.

Por, F. D., Dor, I. \& Amir, A., 1977. The mangal of Sinai: Limits of an ecosystem. - Helgoländer wiss. Meeresunters. 30, 295-314.

Por, F. D. \& Lerner-Seggev, R., 1966. Preliminary data about benthic fauna of the Gulf of Eilat (Aqaba), Red Sea. - Israel J. Zool. 15, 38-50.

Reiss Z., Merling-Reiss, A. \& Moshkowitz, S., 1971. Quarternary planktonic Foraminifera and nannoplankton from the Mediterranean continental shelf and slope of Israel. - Israel J. EarthSci. 20, 141-177.

Rinkevich, B., 1975. On the reproduction of Stylophora pistillata (Esper) and harmful effects of oil on its population. M. Sc. thesis, Tel Aviv University, $80 \mathrm{pp}$.

Rinkevich, B. \& Loya, 1977. Harmful effects of chronic oil pollution on a Red Sea scleractinian coral population. - Int. Coral Reef Symp., Miami, 3, 585-591.

Safriel, C. V. \& Lipkin, Y., 1964. Notes on the intertidal zonation of the rocky shores of Eilat (Red Sea), - Israel J. Zool. 13, 187-190.

Slobodkin, L. B. \& Fishelson, L., 1974. The effect of the cleaner-fish Labroides dimidiatus on the point diversity of fishes on the reef front at Eilat. - Am. Nat. 108, 369-376.

Springer, C. V. \& Smith-Vaniz, W. F., 1972. Mimetic relationships involving fishes of the family Blenniidae. - Smithson. Contr. Zool. 112, 1-36.

Wolodarsky, Z., 1979. Population dynamics of Trapezia crabs inhabiting the coral Stylophora pistillata in the northern Gulf of Eilat (Red Sea) M. Sc. thesis, Tel Aviv University, 81 pp. 